\title{
A Content Analysis of Blog Posts on Angry Library Patrons
}

by

Iris Marigold Operario

Submitted to the School of Information Management,

Victoria University of Wellington

in partial fulfillment of the requirements for the degree of

Master of Information Studies

July 2013 


\section{Abstract}

Research Problem: This exploratory study looks into what is written in blogs regarding angry library patrons. It aims to provide insight on angry library patrons by identifying the themes/issues in the blog posts, the reasons for anger of the library patrons, and to describe the characteristics of the blog post authors.

Methodology: A qualitative content analysis was used to analyse the blog posts. The blog search engine Google Blogs was used to search for the relevant blog posts. A sample of 92 individual and organisational blog posts were read and analysed.

Results: Three main themes emerged in the analysis of the blog posts: 1) the causes of anger which can either be library-related or due to other patrons; 2) how anger was displayed; and 3) the sentiments of the library staff members towards angry patrons. The blog authors mostly come from North America and have a library background.

Implications: Analysing these blog posts provides further insight into angry library patrons which might not otherwise be found in existing anger studies in a library setting and problem library patron research. Uncovering what is said in the blogosphere about angry library patrons will give a picture of a wide range of anger issues which may be relevant for library staff members as they try to better understand angry library patrons. While this study was not able to retrieve as much blog posts from an angry library patron's perspective as originally planned, a study noting the key difference of opinions between angry library patrons and library staff members could be investigated in the future.

Keywords: Angry Library Patrons, Blog Posts, Content Analysis 


\section{Table of Contents}

$\begin{array}{ll}\text { Abstract } & 2\end{array}$

$\begin{array}{lr}\text { 1. Introduction } & 6\end{array}$

Background of the Study $\quad 6$

$\begin{array}{ll}\text { Objectives of the Study } & 7\end{array}$

$\begin{array}{ll}\text { Research Questions } & 7\end{array}$

$\begin{array}{ll}\text { Significance of the Study } & 7\end{array}$

Inclusions and Limitations of the Study 8

2. Literature Review 9

$\begin{array}{lr}\text { On Anger } & 9\end{array}$

Growing Incidents of Anger in the Workplace 9

Causes of Anger in a Library Environment 9

Effects of Anger Towards Library Staff 12

$\begin{array}{ll}\text { On Blogging } & 13\end{array}$

$\begin{array}{ll}\text { Motivations for Blogging } & 14\end{array}$

$\begin{array}{lr}\text { 3. Methodology } & 16\end{array}$

$\begin{array}{lr}\text { Qualitative Content Analysis } & 16\end{array}$

$\begin{array}{lr}\text { Using Blogs as a Data Source } & 16\end{array}$

$\begin{array}{ll}\text { Keyword Searching } & 17\end{array}$

$\begin{array}{ll}\text { Selection of Blogs } & 18\end{array}$

Descriptive Statistics and Data Analysis 19

4. Presentation and Analysis of Data $\quad 20$

$\begin{array}{ll}\text { Research Question } 1 & 20\end{array}$

$\begin{array}{ll}\text { Theme 1: Causes of Anger } & 21\end{array}$

$\begin{array}{ll}\text { Library-related Causes of Anger } & 21\end{array}$

$\begin{array}{ll}\text { Anger Caused by Other Patrons } & 24\end{array}$ 
Theme 2: How Anger was Displayed 26

Theme 3: Library Staff Members' Sentiments on Angry Library Patrons 24

$\begin{array}{ll}\text { Research Question } 2 & 30\end{array}$

$\begin{array}{ll}\text { Individual Blogs } & 31\end{array}$

Library Bloggers 32

Library Patron Bloggers 33

$\begin{array}{ll}\text { Organisational Blogs } & 34\end{array}$

5. Conclusion and Suggestions for Further Research 36

$\begin{array}{ll}\text { 6. References } & 38\end{array}$

Appendix: List of Blogs 


\section{List of Tables}

$\begin{array}{ll}\text { Table 1: Internal and external factors of anger } & 10\end{array}$

$\begin{array}{ll}\text { Table 2: Keywords and search results using Google Blogs } & 19\end{array}$

$\begin{array}{ll}\text { Table 3: Themes of the blog posts } & 20\end{array}$

Table 4: Library-related causes of anger 22

Table 5: Anger caused by other patrons 25

Table 6: How anger was displayed 27

Table 7: Types of blogs $\quad 30$

Table 8: Location of the individual bloggers 31

Table 9: Gender of the individual bloggers 31

Table 10: Blog writer's background 31

Table 11: Location of the organisational blogs 33

Table 12: Subject focus of the organisational blogs 33 


\section{Introduction}

\section{Background of the Study}

Most library patrons are nice, polite, and understanding. But some patrons can be very unpleasant. Anyone working at a service desk in any library has most likely encountered an angry library patron. These incidents may range from the mildly irate patrons to the combative or violent ones. It is no wonder then that angry incidents in libraries have become a daily occurrence that library staff dread (Rubin, 2000).

Osa (2002, p. 266) contends that angry patrons are the most often-encountered problem patrons in the library and that an angry patron is "the most threatening battle a frontline staff has to cope with”. This is why some library staff members have turned to blogging to publicly vent about their interactions with patrons (Farkas, 2007) and to blow off steam about something that upsets them (Pedersen, 2010). Moreover, it has become common for some librarian bloggers to spice their postings with patron stories (Bar-Ilan, 2007).

While research on the library blogosphere or biblioblogosphere (Lee and Bates, 2007, p.648) and librarians as bloggers or bibliobloggers (Stephens, 2008, p. 311) is nothing new, a study of blog posts on angry library patrons has not been done. On anger research in a library environment, much has been written on the library code of conduct policies which must be enforced, the problem situation manuals which need to be created, and the customer care training needed to better manage angry patrons. But no research has been done on what is written in blogs regarding angry library patrons. This gap is the rationale for this study. This exploratory study will look into the blog posts of both patrons and library staff members on the topic of angry library patrons. Perspectives from both patrons and library staff members will be read and analysed to determine the sentiments of the bloggers and the issues expressed in the blog posts. Analysing these blog posts will hopefully provide further insight into angry library patrons which might not otherwise be found in the existing anger research in a library setting. Lastly, this study will contribute to studies on “deviant customer behavior” (Reynolds \& Harris, 2006, p. 95). 


\section{Objectives of the Study}

A lot of library literature has been written on the various techniques to deal with angry patrons. However, a study of blog posts on angry library patrons has not been done. This study aims to provide insight into blog posts on angry library patrons.

Specifically, this study aims:

1. To identify the themes/issues on blog posts on angry library patrons

2. To identify the reasons for anger of the patrons as written in the blog posts

3. To describe the characteristics of the blog authors on angry library patrons

\section{Research Questions}

What is written in blogs about angry library patrons?

Sub Questions:

1. What themes/issues can be identified by an analysis of blog posts on angry library patrons?

2. What are the authorship characteristics of the bloggers?

\section{Significance of the Study}

While much has been written on angry library patrons, research on blog posts on angry library patrons has been overlooked across the library world. Therefore, this study will hopefully generate additional insights on what is written about this topic in the blogosphere. Analysing the wide range of issues covered in the blogs will give a picture of the extent of these issues. The research findings will be relevant for library staff members as they try to understand angry library patrons. 


\section{Inclusions and Limitations of the Study}

Aside from individual blogs, a decision was made to include organisational blogs or those blogs which are authored by a single person or by a set of people and are maintained and affiliated with an organisational entity.

The limitations in this study are the following:

1. Only the blog posts were read and analysed. The comments in the posts, if there were any, were not read and analysed.

2. Only the blog search engine Google Blogs was used to retrieve the blog posts.

3. While there are several possible keyword combinations to look for blog posts on angry library patrons, only seven keywords were used to retrieve the blog posts.

4. Since this is an exploratory study, no recommendations or tips on how best to deal with angry library patrons will be made. 


\section{Literature Review}

\section{On Anger}

\section{Growing Incidents of Anger in the Workplace}

With the loss of civility in society, frontline employees are now more than ever, confronted with anger. Bouts of temper towards public service personnel are on the rise so it is not surprising that "service encounters are a veritable petri dish for customer rage" (Grove, Fisk, \& John, 2008, p. 42). A review of literature shows that customer verbal aggression is becoming increasingly common in various service settings. In one study, around $74 \%$ of flight attendants and railway employees get verbally abused by passengers at least once a month (Boyd, 2002). In another study, around 200 call center employees in US reported that customer verbal aggression occurred around 10 times a day (Grandey, Dickter, \& Sin, 2004). In addition, around 82\% of employees in hotels, restaurants, and bars had either witnessed or been subjected to violent or aggressive behaviour within the past year whereby their working lives had been significantly affected (Harris \& Reynolds, 2003).

While libraries are generally viewed as safe and quiet places to work in, a number of studies have shown otherwise. In 1995, a survey of public library staff in the UK reveals that violent and aggressive behaviour by library customers was a problem for public library staff and that verbal abuse was common and considered part of the job (McGrath \& Goulding, 1996). Farrugia (2001) did a follow-up survey a few years later in Britain and found that violence and verbal abuse were still prevalent in public libraries. In an academic library in Jamaica, verbal abuse was again found to be the most prevalent form of aggressive behaviour towards library staff (Kean \& McKoy-Johnson, 2008). A survey of incidents of unacceptable behaviour in academic libraries in Australia found that that there was an increase in verbal aggression, rudeness, and demanding behaviour by clients (Moorcroft, 2009).

\section{Causes of Anger in a Library Environment}

Steffen (2000) notes that the presence of so many angry customers in libraries is a reflection of the society as a whole. If this is indeed the case, there is a need first to understand what makes library customers angry. Much has been written by library practitioners on possible factors or causes of anger of library customers. While these reasons for display of 
dissatisfaction, rudeness, anger, and aggression are not results of a research study nor were they written by subject experts on anger research, it is still worth knowing the wide and varied possible causes or factors of anger in libraries which were put forward.

One cause of a library customer's frustration and anger according to Osa (2002) is the inability of the library staff to provide needed answers or information. When customers come to the reference desk, they expect the library employee, regardless of his/her position to answer the question and to locate the information. If this need is not met, patrons can become disappointed, frustrated, angry, and unpleasant. This is why Osa (2002) asserts that competence is the most crucial obligation librarians owe to customers. In the same way, it is viewed that most people get angry at the library because their expectations are so high and when one of these expectations are not met, customers become disappointed, frustrated, angry and unpleasant (Turner, 2004). Blessinger (2002) stresses out though that usually the customer is mad at the situation and not the library employee but will get angry with anyone that represents the institution that created their anger.

For people unable to overcome the technology barrier, McGuigan (2002) argues that the constantly changing formats of information, the various types of information tools, the classification systems, and nuances of computer use lead to a certain level of confusion and hostility on certain customers. He adds that librarians should acknowledge that libraries can be confusing and intimidating places for some users.

McGrath \& Goulding (1996) identified the following factors as common reasons for conflict in public libraries: disputes over library records, shortages of books and lack of new material, perceived staff attitude, limited loan periods, opening hours, and fines.

Bee’s 2001 study on problem patrons in New Zealand academic libraries also shows that library fines are the main cause of problem patron incidents. This was due to fines incurred as a result of the late return of short-term loans and recalled items. Aside from fines, queues also turned out to be another reason for problem patron incidents. Although not every person who waited in line became a problem patron, it was said to be an aggravating factor in some cases (Bee, 2001).

Rubin (2000, p. 83) prepared a list of “stress points” which may cause customers to be angry in the library:

- Waiting in line 
- Circulation periods

- Overdue fines

- Reserve policies

- Computers down

- Insufficient internet access stations

- Requirements for getting a library card

- Lack of change for copiers

- Books not on shelf as expected

- Insufficient seating

- Overcrowded programs

- Behaviour of other patrons

- Non-circulating materials

- Broken equipment

- No eating or drinking allowed

Gannon-Leary \& McCarthy (2010, p. 132) came up with a list of internal and external factors causing customers to become angry and aggressive. While the list appeared in a customer care training manual for library staff, the factors listed may be applied to any service industry.

\begin{tabular}{|l|l|}
\hline Internal Factors & External Factors \\
\hline Illness/ pain/ feeling unwell & $\begin{array}{l}\text { Not wanting to lose face in front of } \\
\text { peers/members of the opposite sex }\end{array}$ \\
\hline Mental health problems & $\begin{array}{l}\text { Cultural misperception of what constitutes } \\
\text { rude or impolite behaviour }\end{array}$ \\
\hline Bereavement & Being ignored by staff \\
\hline Divorce/marital problems & Dismissive action of staff \\
\hline Alcohol/drugs & Delays in receiving attention/service \\
\hline Stress of assignments, exams & Queue/line jumping \\
\hline Stress specific to times of year (i.e. & Noise \\
Christmas) & Disruptive behaviour of other customers \\
\hline Money worries & Lack of staff availability to help \\
\hline Hunger/lack of food & Perceived lack of helpfulness in staff \\
\hline Lack of knowledge &
\end{tabular}




\begin{tabular}{|l|l|}
\hline Internal Factors & External Factors \\
\hline Communication difficulties & Perceived lack of interest from staff \\
\hline Past experience & Tardiness for appointments \\
\hline Insecurity/ feeling threatened/vulnerability & Being criticised or blamed \\
\hline False or unrealistic expectations & Response to a stressed-out staff member \\
\hline $\begin{array}{l}\text { Personality type (i.e. individuals who are } \\
\text { impatient, competitive, stress junkies who get } \\
\text { easily upset over small things) }\end{array}$ & Copying another customer's response \\
\hline
\end{tabular}

Table 1: Internal and external factors of anger

\section{Effects of Anger Towards Library Staff}

As mentioned earlier, there is a dearth of information in the library literature on the impact of library customers' anger towards library personnel. The ones below are a few examples from the literature which touched on the emotional reactions of library staff towards customer aggression or outcomes of encounters with difficult patrons.

In the earliest article on stress in library careers, Bunge (1987) reported that relationships with library patrons are both the greatest source of stress and satisfaction for public service librarians. He added that causes for stress include rude, angry, impatient, unrealistic, and/or disturbed patrons. Likewise, Osa (2002) maintains that because library customers can sometimes behave very badly, they have the power to make the job of library staff a joy and/or a living hell. In another study in Taiwan, library customers were found to be the major source of negative emotions among Taiwanese public librarians (Sheih, 2010).

One respondent in McGrath \& Goulding's 1996 study of violence in UK public libraries explained being uncomfortable and nervous about dealing with nasty borrowers, hiding from them, and getting senior staff who are paid more to take the hassle. Another respondent confirmed that dealing with difficult borrowers led to stress which affected customer care because the next person in the queue may not get a good response (McGrath \& Goulding, 1996). McGrath \& Goulding (1996) contends that stress due to dealing with difficult customers in the library may result to a lack of concern for customers, feelings of resentment, and even absenteeism. 
Library staff seriously affected by negative client behaviour are left with a residue of fear, distrust, and suspicion long after the incident is over (Moorcroft, 2009). Some respondents in a study on unacceptable behaviour in Australian academic libraries raised the issue of emotional intelligence noting that if staff knew how to handle their own emotions, recognised stress triggers, and "were more balanced”, they would not be so affected by client behaviour (Moorcroft, 2009, p. 214). This argument may be an insult to some staff affected by negative customer behaviour as it appears to show that someone badly affected by an incident is lacking in emotional intelligence and may also be "unbalanced".

A study on problem patrons in academic libraries in New Zealand reveals that library staff felt wound up, really stressed out, and rattled when faced with a problem patron (Bee, 2001). Several described feeling upset for the rest of the day after the incident and some felt less confident in their ability to deal with conflict situations (Bee, 2001). Bullard (2002) stresses that a staff member needs a minimum of one hour to recover emotionally to be able to continue working efficiently.

When asked how difficult or problem patrons make the reference staff feel in one library in Penn State University Library in US, most participants in the study replied that they felt inadequate/incompetent, frustrated, and angry/irritated towards the patrons (Osa, 2002). Interestingly, some respondents replied that they "looked for ways to quickly get rid of difficult patrons” (Osa, 2002, p. 270) which means that some library staff are understandably less eager to help out some patrons.

On a favorable note though, some reference staff said that after an encounter with difficult patrons, they are challenged to learn more and they are able to identify areas which they need to improve on (Osa, 2002) which are positive outcomes for the staff.

\section{On Blogging}

Blogs or weblogs are frequently updated, reverse-chronological entries on a single webpage (Blood, 2004). One of the main components of a blog is the individually created entry or post. Sauers (2006) classifies blogs in three different types: individual blogs, subject blogs, and organisational blogs. Individual blogs are maintained by individuals and commonly personal in nature. They take the form of online diaries or "self-narratives" (Hookway, 2008, p. 93) 
and the blogger's personal experiences or professional life are detailed. This is the original blog style and this is the type of blog which most people are familiar with.

Another type is the subject blog which is maintained by one or more persons and deal with a particular subject (Sauers, 2006). This can be on any other topic under the sun. The last type is organisational blogs which represent the views, opinions, and events of an organisation (Sauers, 2006). A perfect example of this is the official blog of a library. Other researchers have come up with their own blog classification. Bar-Ilan (2007) classifies blogs according to authorship (single, group, communal), content (personal or topic oriented), and by format (essays, lists of sites, announcements). Sauers (2006) explains however that many blogs may fall into more than one category or may not fit into any of them and there is technically no clear cut rule in categorising blogs.

\section{Motivations for blogging}

Through the years, several studies have been done to understand the bloggers' motivation for blogging. Most of these studies though have focused only on the personal journal type of blogs. Dvorak (2002) presents the following reasons: a need to share, a need to publish, ego gratification, elimination of frustration, and anti-depersonalisation. Nardi, Schiano, Gumbrecht, and Swartz (2004) studied the blogging community at Stanford University and offers these reasons for blogging: to update others on activities and whereabouts, to provide commentary and opinions, to articulate ideas through writing, to form and maintain communities or forums, to express deeply felt emotions and to release emotional tension.

In the library and information studies' field, Stephens' (2008) landmark study on librarian bloggers shows that their motivations are based around themes of sharing, participation in the library community, and enhanced professional development. Bibliobloggers also blog to express their feelings, to have an outlet to tell a story, and as a way to vent frustrations with their jobs or the profession (Stephens, 2008). In a similar survey done by Farkas (2007) on the library blogosphere, it appears that most librarians blog mainly about their lives and hobbies and distinction between a personal and a professional blog is not clear. They are inclined to blog for the following reasons: to share ideas with others, to build a community, to contribute to the profession, and to reach out to patrons (Farkas, 2007). While it is not unusual for librarians to blog about patrons, this is not sanctioned in blogs maintained by 
libraries. Frequently updated library blogs assist librarians in communicating with their patrons, get support for new initiatives, and market programs, collections and services (Brookover, 2007). 


\section{Methodology}

\section{Qualitative Content Analysis}

This study used qualitative content analysis to understand the blog posts. Qualitative content analysis is "a research method for the subjective interpretation of the content of text data through the process of coding and identifying themes or patterns” (Hsieh \& Shannon, 2005, p. 1278) or as simply put by Neuman (2012, p. 239) it is "a research technique for gathering and analysing the content of text”. The "content” refers to words, pictures, symbols, ideas, themes, sounds, colors or anything that communicates meaning or message to people (Neuman, 2012). The "text” can either be books, newspaper and magazine articles, advertisements, speeches, web pages, musical lyrics, and many others (Neuman, 2012).

Content analysis can either be quantitative and qualitative in approach (Beck \& Manuel, 2008; Spurgin \& Wildemuth, 2009). In a quantitative content analysis, the focus is on the counting of things or numerically measurable objectives (Beck \& Manuel, 2008). By contrast, qualitative content analysis pays attention to unique themes of particular texts and explicit and hidden messages or meanings may be uncovered (Neuman, 2012). However, with content analysis, the truthfulness of an assertion cannot be determined and the content's significance may not be interpreted (Neuman, 2012).

Content analysis is widely used in library and information science studies (White \& Marsh, 2006; Beck \& Manuel, 2008) because it is "non-reactive, unobtrusive, and not limited by geography” (Beck \& Manuel, p. 38). It is non-reactive and unobtrusive because instead of directly studying people or human behaviour, textual evidence of their behaviour or actions is examined which means that it is exempted from review by an institutional human ethics committee (Beck \& Manuel, p. 38). Because it is not confined to a specific area, researchers can easily study content made locally and from another part of the world.

\section{Using Blogs as a Data Source}

In this study, blogs will be the primary source of data. It is an easy, quick, and inexpensive tool for collecting research data as compared to surveys and interviews (Shah \& Robinson, 2011; Hookway, 2008). Moreover, data can be readily compiled. Because blogs are publicly available data, the time-consuming process of getting ethical approval is avoided (Shah \& 
Robinson, 2011) and participant consent is not necessary (Sudweeks and Rafaeli, 1995;

Walther, 2002). Lastly, since the data being analysed is available in the public domain, information reported in this data is considered as secondary data.

On the other hand, using blogs as the primary data source raises concerns on whether bloggers are telling the truth. Hookway (2008) argues that that this does not really matter because blogs still tell us something about the manner in which specific ideas are constructed. In the same way, someone who fills up an online survey or who is being interviewed may not necessarily be telling the truth so truthfulness may not be completely guaranteed.

\section{Keyword Searching}

The blog search engine Google blogs was used to find blog posts on angry library patrons throughout May 2013. The following keywords were used to search the relevant blogs:

frustrated library patron

upset library patron

angry library patron

complaining library patron

accusatory library patron

furious library patron

unacceptable behavior library patron

The keywords “frustrated”, “upset”, “angry”, “complaining”, “accusatory”, “furious”, and "unacceptable behavior" are the seven degrees of anger in their rising levels of intensity which is often exhibited by an angry library patron (Rubin 2000, p. 8). Rhea Joyce Rubin wrote a book in 2000 on handling angry library patrons entitled "Defusing the angry patron: a how-to-do-it manual for librarians and paraprofessionals” and it appears that this is the unofficial guide for library workers on handling angry library patrons. A second edition was published in 2010. This book alone has been mentioned in 16 blog posts analysed in this study and it is even a required reading in a few library schools in the US. Rubin may not have 
based her writings on a previous research, instead, the manual she wrote was based on her experiences as a prison librarian in Chicago in the 1970s (Rach, 2011).

While many other similar keywords (i.e. yelling, irate, verbally abusive, hostile, argumentative, etc.) and different combinations of keywords (i.e. angry library borrower) could have been used to search for blog posts, the seven keyword searches already provided enough data and it was not my intention to compile an exhaustive sample. Moreover, due to a very limited time available, only a manageably small sample was analysed for the study as having a large sample will require a substantial time for analysis.

The phrase "library patron" was used as the search term as this was undoubtedly the preferred term of the bloggers. Attaching the word patron to one of the seven degrees of anger mentioned by Rubin (i.e. frustrated library patron) yielded several relevant results whereas using other terms like "frustrated library customer”, “frustrated library user”, “frustrated library borrower”, and "frustrated library client” continuously yielded several irrelevant results. Additionally, "patron" continues to be the term most commonly used by librarians and as Reed (2008, p. 184) has stated "From Dewey to databases, the word patron has stood the test of time”. "Customer" ranks second in popularity but this term remains controversial, typically avoided by most librarians (Mathews, 2010), and has commercial overtones (Reed, 2008). Gorman (1983, p. 597) does not prefer the word "client" as it is associated with "shifty lawyers and overpaid realtors" while "user" is associated with drug users as Gorman (1983) points out. He also referred to this confusion as “client/borrower/user/patron/reader complex" (Gorman, 1983, p. 597) and suggested that the library magazine American Libraries sponsor a contest to find a suitable term.

In this study however, I chose to use the term patron to simplify things because almost all of the literature I have read used patron and the blog posts retrieved used this term as well.

\section{Selection of Blogs}

For purposes of this study, a "blog post on angry library patrons" is a blog post authored by anyone whose topic touches on angry library patrons. This can either be the main topic of the blog post or something which the blog post has mentioned. To identify the pertinent blogs to study, the first 50 results of each keyword search (i.e. frustrated library patron) in Google 
blogs were analysed. Because there were seven keyword searches made, this resulted to a total of 350 blogs which were reviewed and read. After removing irrelevant posts, a final sample of 92 blog posts was selected based on the following criteria:

1. The main theme of the blog post was on library and information management.

2. The content of the post conveys an angry library patron and not someone/something else (i.e. angry birds, angry librarians). This is regardless of whether the post was written by a library staff member or a patron or single-authored or group-authored or an individual blog or an organisational blog. Unfortunately, quite a lot of the blog posts retrieved were on angry, frustrated, upset, and complaining library workers and not library patrons which is not what this study is about.

3. The blog post must be written in English.

4. The blog post must be active throughout the data collection period (May 2013).

The list of blogs in this study is found in the appendix.

\section{Descriptive Statistics and Data Analysis}

Before doing a qualitative content analysis, a preliminary statistical analysis was done to describe the basic features of the data in the study. This provided a simple summary about the sample.

The unit of analysis in this study was the main idea of the blog post. In order to do an analysis of the blog posts, an “inductive/clustering approach” (Aharony, 2009a, p, 591) was used to make a list of coding categories and their attributes. This approach has been done in several librarian blog studies (Gelber, 2011; Aharony, 2010; Aharony, 2009a; Aharony, 2009b) and it involves compiling a list of main ideas which were then combined into clusters containing similar topics as the content of the blog posts were read and analysed. Recurrent themes and categories for new concepts were noted down and new categories were devised whenever a new topic did not match any previous category (Aharony, 2010). 


\section{Presentation And Analysis of Data}

Using Google Blogs, seven keywords were used to search for the relevant blog posts on angry library patrons. Only the first 50 results of each keyword search were read and analysed. Out of these 350 blog posts, 92 blog posts were relevant for this study which is only $26 \%$ of the initial sample. But due to time constraints, I believe this was enough sample to proceed with the study. Table 1 shows the number of hits.

\begin{tabular}{|c|c|c|}
\hline Keywords Used & $\begin{array}{c}\text { Number of Blog } \\
\text { Posts Retrieved }\end{array}$ & Percentage \\
\hline Frustrated library patron & 14 & 15.22 \\
\hline Upset library patron & 13 & 14.13 \\
\hline Angry library patron & 33 & 35.87 \\
\hline Complaining library patron & 22 & 23.91 \\
\hline Accusatory library patron & 0 & 0 \\
\hline Furious library patron & 2 & 2.17 \\
\hline $\begin{array}{c}\text { Unacceptable Behaviour } \\
\text { library patron }\end{array}$ & 8 & 8.70 \\
\hline Total & $\mathbf{9 2}$ & $\mathbf{1 0 0}$ \\
\hline
\end{tabular}

Table 2: Keywords and search results using Google blogs

Around 35\% of the blog posts retrieved referred to an angry library patron which shows that this is still the most common word used by everyone to describe someone who is displaying his/her displeasure with the library as opposed to irate, rude, or furious (which got only two hits). The keyword to get the second most number of results is the complaining library patron which got 22 hits or 23\% which seems to show that library patrons often have complaints. For some reason, there were no hits for an accusatory library patron which shows that either not many library patrons have an accusatory attitude or this is simply not a common term used to describe an angry library patron.

\section{Research Question 1: What themes/issues can be identified by an analysis of blog posts on angry library patrons?}

From the qualitative content analysis of the blog posts on angry library patrons, three main themes emerged as shown in table 3. 


\begin{tabular}{|l|}
\hline \multicolumn{1}{|c|}{ Themes } \\
\hline Causes of anger \\
\hline How anger was displayed \\
\hline $\begin{array}{l}\text { Library staff members' sentiments towards } \\
\text { angry library patrons }\end{array}$ \\
\hline
\end{tabular}

Table 3: Themes of the blog posts

\section{Theme 1: Causes of Anger}

Majority of the blog posts were on the causes of anger which can either be library-related or caused by other patrons.

\section{Library-related Causes of Anger}

Four of the library-related causes as detailed in table 4 are surprisingly due to the patrons' frustrations in technology which can be because of computers, the integrated library management system, e-books, and music downloads. Computers and the internet may have dramatically changed the way patrons access information but they have also brought its accompanying difficulties which can be exasperating for some patrons. This is similar to what McGuigan (2002) maintains that libraries can be confusing and intimidating places and that the latest technology can sometimes bring potential anxiety and subsequent hostility amongst patrons.

One blogger described in her blog her online conversation with a friend who was clearly frustrated with library catalogues. While the frustrated friend may not yet be angry, being frustrated is the first degree of anger in Rubin's seven degrees of anger.

[09:47] Friend: catalogs are so finicky!

[09:47] Nicole: yep

[09:47] Nicole: what's the matter now?

[09:47] Friend: sheesh 
[09:48] Friend: i just want a listing of the books on CD that the

Independence library has on hand. i can pick one out and run in and get it at noon when they open. i dont have time to browse there. and browsing the books on $C D$ is so...not fun

[09:50] Friend: and they have these "overdrive audio books" but i dont know what the heck that means

[09:50] Nicole: 9

[09:50] Friend: yeah

[09:50] Friend: silly libraries

[09:51] Friend: i even called someone at the central library to ask if they knew how to get the results $i$ wanted... he didnt know (From the blog post “Patrons' frustrations” by Nicole Engard).

On the other hand, while some patrons may not be well-versed when it comes to certain technology (i.e. not knowing how to play an audio book), others are far more technologicallyproficient and are avid users of e-books and music downloads.

Misunderstandings or a perceived unjust treatment from a staff member may also contribute to a patron's anger. Simply asking for some clarifications from a patron or not making eye contact can be a trigger for anger. Being jobless and broke and even the lack of books on the "Indian tribe of Chechnya in Iraq" can push someone to the edge. The staff member is clearly no longer at fault in these cases but due to the patron's situation or possible personality type, an angry encounter still takes place. As Grove, Fisk, \& John (2004, p. 43) have said “... some customers enter a service encounter with their rage sensors loaded and ready”. There are also times when a patron is entitled to be angry. In one blog post, a patron complained after being bitten by a bedbug found in one DVD which was borrowed from a Connecticut Library in US. 


\begin{tabular}{|c|c|}
\hline Library-related cause & Reasons for Anger \\
\hline \multirow[t]{7}{*}{ Technology-related } & Library computers were acting up \\
\hline & Not having enough computers in the library \\
\hline & Library's internet filter is blocking too much \\
\hline & $\begin{array}{l}\text { Frustrated when navigating through the databases and } \\
\text { other online technologies }\end{array}$ \\
\hline & Finicky catalogues \\
\hline & $\begin{array}{l}\text { An audio-book cannot be played on the patron's DVD } \\
\text { player }\end{array}$ \\
\hline & $\begin{array}{l}\text { The add value machine (used for topping up a library card) } \\
\text { does not provide change for large bills }\end{array}$ \\
\hline \multirow[t]{4}{*}{$\begin{array}{l}\text { Integrated Library } \\
\text { Management System } \\
\text { (ILMS)-related }\end{array}$} & No notification was received for a reserved book \\
\hline & $\begin{array}{l}\text { Cataloguing mix-up on the record which made the book } \\
\text { unable to be located }\end{array}$ \\
\hline & $\begin{array}{l}\text { Allowing social tagging in the catalogue which lets people } \\
\text { make political statements }\end{array}$ \\
\hline & Ads appear at the back of date due receipts and hold slips \\
\hline \multirow[t]{6}{*}{ E-books } & $\begin{array}{l}\text { Limited selection and availability of e-books in public } \\
\text { libraries }\end{array}$ \\
\hline & $\begin{array}{l}\text { Frustrated by the lack of flexibility in the current } \\
\text { downloading procedures of e-books }\end{array}$ \\
\hline & Digital rights management (DRM) restrictions on e-books \\
\hline & Long waiting list to borrow e-books \\
\hline & Check-out process for e-books \\
\hline & Buying more e-books instead of printed books \\
\hline \multirow[t]{3}{*}{ Music downloads } & Freegal's three songs per week limit is not sufficient \\
\hline & $\begin{array}{l}\text { Freegal only allows songs from Sony music to be } \\
\text { downloaded }\end{array}$ \\
\hline & $\begin{array}{l}\text { Need to schedule yourself out for a month's worth of } \\
\text { downloads to get a full album is not realistic }\end{array}$ \\
\hline \multirow[t]{5}{*}{$\begin{array}{l}\text { Perceived slight from } \\
\text { library staff members }\end{array}$} & $\begin{array}{l}\text { After asking for clarifications on what kind of graffiti } \\
\text { books the patron wants, he becomes angry and says he is } \\
\text { not a criminal but an artist }\end{array}$ \\
\hline & $\begin{array}{l}\text { Not making eye contact after a tape dispenser was handed } \\
\text { over to a patron }\end{array}$ \\
\hline & $\begin{array}{l}\text { Perceived impatience of the librarian in talking to a deaf } \\
\text { patron }\end{array}$ \\
\hline & Thinks the Library does not care about women's safety \\
\hline & The librarian made the patron feel stupid \\
\hline \multirow[t]{2}{*}{$\begin{array}{l}\text { Library staff members' } \\
\text { mistake }\end{array}$} & Given wrong information on the phone \\
\hline & Patron's name was spelled incorrectly in the library record \\
\hline
\end{tabular}




\begin{tabular}{|c|c|}
\hline Library-related cause & Reasons for Anger \\
\hline \multirow[t]{7}{*}{ Library Policies } & $\begin{array}{l}\text { The books on hold with the names of patrons who } \\
\text { requested them are displayed on the shelves and can be } \\
\text { seen by anyone }\end{array}$ \\
\hline & $\begin{array}{l}\text { The patron does not know that a recall request is not } \\
\text { immediate }\end{array}$ \\
\hline & Overdue fines \\
\hline & $\begin{array}{l}\text { A book which was borrowed less than an hour ago was left } \\
\text { behind by a patron and got checked in. As the book is very } \\
\text { popular with hundreds of holds on it, the patron had to } \\
\text { wait again for her turn. }\end{array}$ \\
\hline & $\begin{array}{l}\text { Lack of policy not allowing kids to borrow sexually } \\
\text { explicit books }\end{array}$ \\
\hline & $\begin{array}{l}\text { Lack of policy in preventing porn to be viewed in the } \\
\text { library }\end{array}$ \\
\hline & $\begin{array}{l}\text { Why some books are weeded out just because they are not } \\
\text { checked out enough }\end{array}$ \\
\hline \multirow[t]{4}{*}{$\begin{array}{l}\text { Censorship/Intellectual } \\
\text { freedom }\end{array}$} & $\begin{array}{l}\text { "Challenged books" and other sexually explicit books still } \\
\text { remain on the shelves }\end{array}$ \\
\hline & $\begin{array}{l}\text { A bestseller with curse words in the title and throughout } \\
\text { the book remains on the shelves }\end{array}$ \\
\hline & racy Gossip Girl books \\
\hline & A gay-themed exhibit in the library \\
\hline \multirow[t]{3}{*}{ Library layout } & Poor signage in the library \\
\hline & The loss of book stacks and carrels in the library \\
\hline & Small library space \\
\hline \multirow[t]{6}{*}{ Others } & Long lines \\
\hline & $\begin{array}{l}\text { Accused by a library staff member of water damaging a } \\
\text { book }\end{array}$ \\
\hline & Frustrated that some books cannot be located in the stacks \\
\hline & Bitten by a bedbug found in a DVD from a library \\
\hline & $\begin{array}{l}\text { The library does not own books on the "Indian tribe of } \\
\text { Chechnya in Iraq" }\end{array}$ \\
\hline & $\begin{array}{l}\text { Upset about being unemployed and broke thus passing his } \\
\text { anger towards the staff member }\end{array}$ \\
\hline
\end{tabular}

Table 4: Library-related causes of anger

\section{Anger Caused by Other Patrons}

In anger studies in a library environment, anger is usually attributed to the library itself, its staff members, and some unpopular library policies (i.e. fines). Anger caused by other fellow patrons has not been looked into. Table 5 shows some of the friction points on why some patrons become angry with the behaviour and actions of other patrons in the library. 
Some of the issues by the bloggers can also be linked to technology/computer use which can be due to the habits of the online porn-viewing patrons and patrons who use computers for hours on end.

Noise understandably annoys a lot of people which is why even a regular patron who frequently passes gas makes other patrons (and other library staff nearby) complain and squirm in horror with the "noise-related and/or smell-related" problem (from the blog post "Public library patron flatulence”). Noise due to the computer/electronic gadgets of other patrons is also an issue amongst patrons. This shows a lack of consideration and basic courtesy to others. Patrons who sing to the music with their headphones on may be forgiven for unintentionally disturbing others but sounds from someone blatantly watching online porn is hard to stomach.

Here are two blog posts from patrons who complain about the noise levels in their library.

... Loudness is by far the biggest irritation to library patrons. ... the one thing that can detach our work's attention is sound. Someone's loud talking, laughing, banging, crashing, screaming, whatever it is that reaches clear detectability, is beyond an annoyance if it breaks a lucid thought or pattern of study... (from the blog post "Studying at the library: bad patron behaviors"; anonymously written in Stateuniversity.com)

... Libraries once served as refuges against noise. Now the library's cacophony makes an iPod necessary equipment to drown out the din.... (from the blog post "A library patron observes his surroundings and finds many reasons to complain” by Daniel Flynn).

Another theme from the list is hygiene issues. Offensive body odor was mentioned several times as complaints by both patrons and library staff members. Even someone wearing way too much perfume is an issue for patrons with allergies. One library in Indiana in US in fact has implemented a hygiene policy for all their patrons (from the blog post "Help! I'm a librarian not a social worker" by Carolyn Brewer). 


\begin{tabular}{|c|c|}
\hline Patron-related causes & Reasons for Anger \\
\hline \multirow[t]{4}{*}{ Porn } & $\begin{array}{l}\text { A long wait to use the computers while others are just } \\
\text { watching porn }\end{array}$ \\
\hline & A patron is pleasuring himself while watching porn \\
\hline & Watching porn while children are present \\
\hline & Loud sounds from porn videos \\
\hline Computer Use & Using computers only to play games or log in to Facebook \\
\hline \multirow[t]{7}{*}{ Noise } & Patrons who have headphones are singing to the music \\
\hline & Unattended children \\
\hline & Loud electronic devices \\
\hline & Loud make-out sessions \\
\hline & Loud talking, laughing, singing, and cursing \\
\hline & Mobile phone conversations \\
\hline & Flatulence (may be smell-related as well) \\
\hline \multirow[t]{3}{*}{ Homelessness } & The homeless' body odour \\
\hline & Homeless people sleeping inside/outside the library \\
\hline & $\begin{array}{l}\text { Bathing, changing clothes, washing their hair, and doing the } \\
\text { laundry in library restrooms }\end{array}$ \\
\hline \multirow[t]{4}{*}{ Smell-related } & Flatulence (may be noise-related too) \\
\hline & Offensive personal hygiene \\
\hline & Smells strongly of perfume \\
\hline & Taking off shoes and socks \\
\hline \multirow[t]{5}{*}{ Others } & $\begin{array}{l}\text { A mother breastfeeding her baby while typing on the library } \\
\text { computer }\end{array}$ \\
\hline & $\begin{array}{l}\text { Perceived drug deals and drug use happening outside the } \\
\text { library }\end{array}$ \\
\hline & Using foul language and gathering at the library entrance \\
\hline & Masturbating patrons \\
\hline & $\begin{array}{l}\text { Becomes angry when she hears other patrons say librarians are } \\
\text { jerks }\end{array}$ \\
\hline
\end{tabular}

Table 5: Anger caused by other patrons

\section{Theme 2: How Anger Was Displayed}

In detailing their encounters with an angry patron, the bloggers often described what made the patron angry but they were less detailed in describing how anger was displayed. It may be that patrons in those incidents exhibited a relatively mild form of anger (i.e. raised voice, sarcastic tone, raised eyebrows, etc.) which did not involve hysterics or aggression. One blogger was quite 
detailed in her post about the cause of anger and how anger was manifested in three separate incidents.

1. The guy who shouted at me for 10 minutes about how rubbish our computers were and how it was my fault that he'd been here for an hour and got nothing done... He was right about the computers but not about it being my fault. I infuriated him even further by agreeing with him and trying to get him to fill out a complaint form so we could use his experiences to talk to IT which is not what he cared about, he cared about his wasted time.

2.The chap who had been given the wrong information over the phone and therefore exploded at the Helpdesk and whinged at me about how we'd wasted half an hour of his time that he'd never get back.

3. The lady who, in my second week in the job, said that the Library didn't care about the safety of women on campus and she hoped I got raped.... The woman was clearly at the very end of her tether and was standing outside getting some fresh air. Some boys were out there too and one spat on the ground; she interpreted this as threatening and went into a screaming meltdown. Fun! (From the blog post "Angry person is angry!" by Don't call me Miss!)

Table 6 shows a few of the ways in which library patrons have exhibited their anger as mentioned by the bloggers. I classified them as relatively mild or severe. Many people will argue of course that theft and mutilation of library items should not be considered as a relatively mild form of showing anger. But these two acts do not involve intimidation, aggression, and violence towards another person so I deemed them to be less severe. The most acceptable form of anger in the list is writing in the library's online suggestion box which most library employees who had an angry encounter can only dream of happening. From the short list, it also seems that the patrons' anger may be directed towards books (i.e. by writing or urinating in them) or towards the library personnel. As Patterson, McCollKennedy, Smith \& Lu (2009, p. 7) have said, "When anger reaches a boing point, neither people nor property is safe”. 


\begin{tabular}{|l|l|}
\hline Relatively mild & By writing in books \\
\cline { 2 - 2 } & Not returning items \\
\hline \multirow{5}{*}{ Severe } & Writing in the library's online suggestion box \\
\cline { 2 - 3 } & Terse words at the reference desk \\
\hline & $\begin{array}{l}\text { Shouted at the librarian for } 10 \text { minutes about how rubbish the } \\
\text { library computers are }\end{array}$ \\
\hline & Screaming and shouting \\
\hline By yelling obscenities \\
\hline & By urinating in books \\
\hline & Threatened to knock the library staff member's head off \\
\hline & Threatened to beat the library staff member's backside \\
\hline & $\begin{array}{l}\text { Angrily dropped the library materials on the desk and almost } \\
\text { hit the library staff member }\end{array}$ \\
\hline Wished the librarian gets raped \\
\hline & By slashing the librarian's tires \\
\hline
\end{tabular}

Table 6: How anger was displayed

\section{Theme 3: Library Staff Members' Sentiments on Angry Library Patrons}

In most of the blog posts, library employees have a resigned and understanding attitude towards angry patrons. It is viewed as part and parcel of public service and something which they cannot escape from. Some simply take things in stride and look at the funny side of things.

What I really hope is that none of us ever have to deal with anyone

like this [an angry patron] ever, but that's not very likely in our line of work! So chin up, and hide some emergency chocolate in your bottom drawer, you're going to need it one day. (From the blog post "Angry person is angry!" by Don't call me Miss!)

You need a thick skin to deal with frustrated patrons, and the patience to try and help them work through whatever their problem is, regardless of cause or fault... It's not fun dealing with those same people when they're frustrated and having to be sympathetic, because as librarians we can forget that it's not always as easy for our patrons and that our systems don't always make sense to anyone but us... (From the blog post "Circulation librarians: patron saints of borrowers" by Theresa Schultz of LIS New Professionals Network) 
... how wonderful would it be to have ALA Patron Awards? A National Competition...it would be quite cathartic for all of us, really... a large scale version of those conversations we have over and over again in the backroom or during lunch break. Like the Academy Awards of weirdness ... One category is Most Angry Patron ... (From the blog post "Patron awards" by Christine).

One blogger wished her MLIS offered a Library 101 course solely for dealing with difficult people in the library. The closest thing this comes close to is perhaps the Reference course but handling difficult patrons is often seen as basic interpersonal skills or basic customer service skills and no one sees the toll anger and aggression can have on someone's well-being.

... I wish I had more training in dealing with difficult patrons, including the mentally ill, or just plain angry. It can take some time before you find the right approach for working with the various types of patrons who use the library... (from the blog post "For the future: what today's youth services librarian want the next generation to know” by Kelly Keefer)

Another blogger has had extreme experiences in the public library she has worked in and does not at all consider it as a safe place. Nevertheless, the tone of her blog post does not show at all that she is cowering in fear.

We'd witnessed things in our libraries that were far from safe. I've been flashed, I've caught patrons watching child pornography on library computers (run-of-the-mill porn watchers are too common to count), I've had my tires slashed by an angry patron, I've received death threats (none that I considered serious), and I've had a stalker... I love working at the public library. ... But do I feel safe? Not always. "Safe" is not even a word that should be uttered in the same breath as "public library"... (From the blog post "The Library as a safe place”; anonymously written in Librarians Hit Dot Com Website)

One blogger has linked his angry encounters to lunar effects and has even subtitled his blog post as "Losing faith in humanity one library patron at a time?" 
Glad I didn't work today, after yesterday, where I seemed to get every difficult or angry patron...I bet it's because it's full moon. True fact, library patrons are crazier when there's a full moon! (by yoru_yume)

Another one has had a bizarre dream on angry patrons.

Last night was the first time my slumbering mind combined a zombie dream with a work-related library dream... one of them was also an angry library patron who kept yelling at me when I kept spelling her name wrong on the computer and was up to all sorts of mischief whenever we looked away, gnawing her way out of her cage, slicing her way through the window screen to escape... (From the blog post” Zombies, libraries, and my weird, weird head" by Kristy Bowen).

Surprisingly, from the sample of blogs, no blogger wrote about being seriously affected by an angry patron and left suffering from short-term or long-term psychological or emotional effects. Apart from the tire-slashing incident and the death threats received (the blogger did not say if they were sent by angry patrons) which should naturally not be taken lightly, no blogger mentioned having reduced levels of job satisfaction or experiencing burnout or feeling inadequate and incompetent or wanting to transfer to a new job. This could mean that the library personnel do feel wound up with angry patrons but they are still confident in their ability to deal with conflict situations and are still happy to stay on in their jobs. It is also possible though that had there been a different set of keywords (i.e. violent, verbally abusive, aggressive, etc.) used, more serious psychological and emotional effects on library employees may have been uncovered. Another possibility is that the bloggers don't want the public to know how badly affected they were as it may be viewed as a sign of weakness. One common theme in angry library patron studies which was missing though from the blog posts is the description of how the staff reacted during and after the angry encounter.

\section{Research Question 2: What are the authorship characteristics of the bloggers?}

While blogs are generally viewed as personal narratives of an individual, a lot of blogs these days are organisational blogs or those ones which are affiliated with an organisation (Crosby, 
2010). It is for this reason that more than $56 \%$ of the blog posts retrieved in Google Blogs for this study are not written by an individual blog author as shown in table 7 .

\begin{tabular}{|l|r|r|}
\hline \multicolumn{1}{|c|}{ Type of Blog } & \multicolumn{1}{c|}{ Number of Blogs } & \multicolumn{1}{c|}{ Percentage } \\
\hline Individual & 40 & 43.48 \\
\hline Organisational & 52 & 56.52 \\
\hline Total & $\mathbf{9 2}$ & $\mathbf{1 0 0}$ \\
\hline
\end{tabular}

Table 7: Type of blogs

\section{Individual Blogs}

\section{Library Bloggers}

While there were 40 individual blog posts in this study, there were actually only 36 individual bloggers. Two bloggers had two posts each and another one had three posts which were relevant to this study. There were also six bloggers who chose to remain anonymous by using nicknames. All other bloggers indicated either their first name, the first letter of their first name and last name, or their full name.

The bloggers mostly come from North America with 29 from USA and 5 from Canada. There was one blogger each from England (an American working in a university library in London) and Australia. It would have been more interesting if posts from other nationalities and cultures have been retrieved to have their point of view and compare their views to Western cultures. In one study of customer rage incidents, it was noted that unlike the Westerners, there is a reluctance to openly complain and display a negative emotion in Eastern cultures (Patterson, McColl-Kennedy, Smith \& Lu, 2009). Their study also showed that Asian customers tend to nod in agreement and even smile even if they are actually seething inside (Patterson, McColl-Kennedy, Smith \& Lu (2009). But due to language barriers, it was not possible to retrieve blog posts from nonEnglish speaking countries. 


\begin{tabular}{|l|r|r|}
\hline \multicolumn{1}{|c|}{ Country } & \multicolumn{1}{c|}{ Number } & Percentage \\
\hline Canada & 5 & 13.88 \\
\hline USA & 29 & 80.56 \\
\hline Australia & 1 & 2.78 \\
\hline England & 1 & 2.78 \\
\hline Total & $\mathbf{3 6}$ & $\mathbf{1 0 0}$ \\
\hline
\end{tabular}

Table 8: Location of the individual bloggers

More than $77 \%$ of the bloggers were mostly females as shown in table 9 which could be due to more women in the library profession or as Pedersen (2010) points out, blog writing which is similar to diary writing is still seen as a feminine genre. Moreover, North American studies on blogging show that women bloggers persevere longer in blogging and tend to write more than their male counterparts (Pedersen, 2010).

\begin{tabular}{|l|r|r|}
\hline \multicolumn{1}{|c|}{ Gender } & Number & \multicolumn{1}{c|}{ Percentage } \\
\hline Female & 28 & 77.78 \\
\hline Male & 8 & 22.22 \\
\hline Total & $\mathbf{3 6}$ & $\mathbf{1 0 0}$ \\
\hline
\end{tabular}

Table 9: Gender of the individual bloggers

There were 29 bloggers who has a library background. Out of these 29 bloggers, 26 are working in a library while one works as an Instructor at a Canadian Library School. Another one is a former librarian who currently works for a library vendor and another one is currently pursuing her master’s degree in Library and Information Science (MLIS).

\begin{tabular}{|l|r|r|}
\hline \multicolumn{1}{|c|}{ Blog writer } & Number & \multicolumn{1}{c|}{ Percentage } \\
\hline Has a library background & 29 & 80.56 \\
\hline Patron & 7 & 19.44 \\
\hline Total & $\mathbf{3 6}$ & $\mathbf{1 0 0}$ \\
\hline
\end{tabular}

Table 10: Blog writer's background

There were 12 bloggers who have a master's degree in Library and Information Science (MLIS) while 16 did not indicate in their profile page if they have this degree. The MLIS student blogged about her unfortunate experience as a patron who was accused of water damaging a book. 
... Though I've been a library patron since age two, I was never an angry patron until the other day when I discovered that my library account is "delinquent." When I asked why, I was informed that I caused "severe water damage" to a book and my account is delinquent "pending assessment of a fine." Me: What? Which book? How is that possible? May I see this alleged water damage?

The woman working at the circulation desk avoided eye contact with me throughout our whole conversation. She explained to her computer screen that when I returned the book (nearly two months ago) she remembers that it was "very damaged." She personally marked it as such and flagged my account. ... Clearly this librarian (?) needs to read Defusing the Angry Patron. She demonstrated terrible nonverbal communication skills and used "the library F word."... (From the blog post "Irony: library student with delinquent patron record" by Joanna)

While the bloggers who have a library background mentioned in their blogs their job title, they were not as eager to divulge to the public where they work. Only nine out of 29 library bloggers indicated the type of library where they work in although from the posts of the bloggers, it can be assumed that most of them work in a public library. Five bloggers indicated they work in a public library, two in a medical library, another one works in a university library, and the last one works in a research library. Lastly, only one included in her profile page the name of the institution where she works in. This somehow shows that bloggers still do not want their posts to be associated with or traced back to their library employers.

\section{Library Patron Bloggers}

This study wanted to get as much perspectives as possible from patrons. Unfortunately, only seven or a mere $19 \%$ of the individual blogs in this study were authored by a library patron. Hence, it did not become possible to pursue a third research question I had in mind which was to look into the anger perspectives of both library staff members and library patrons. 
Interestingly, two of the library patrons previously worked in a library. Five of these patrons identified themselves as a writer, a library advocate, a divorced mum, a graphic designer, and a project manager for a publisher. Two patrons did not indicate their jobs.

\section{Organisational Blogs}

Blogs were typically written by one person and presented only one point of view. However, a lot of the very popular blogs these days like the news aggregator site The Huffington Post and the entertainment news site $T M Z$ have a number of authors and contributors. Some organisational blogs may look at first glance like any other website but there are still tell-tale signs that those websites are blogs. The words "Powered by Wordpress", "Blog home”, and "Archive" are found in the page. Crosby (2010) explains that some of the software platforms used for some blogs are so dynamic and so easy to use that they are being used for full websites. Many of these blogs allow the blog owners to easily update the content even with little web content management knowledge (Crosby, 2010).

The same as with the individual blogs, more than $90 \%$ of the organisational blogs come from the USA.

\begin{tabular}{|l|l|l|}
\hline Country & Number & Percentage \\
\hline Canada & 3 & 5.77 \\
\hline USA & 48 & 92.31 \\
\hline UK & 1 & 1.92 \\
\hline Total & $\mathbf{5 2}$ & $\mathbf{1 0 0}$ \\
\hline
\end{tabular}

Table 11: Location of the organisational blogs

With the main content of the blogs, 26 blogs or 50\% are library-related. A few examples are a library law blog, a new library professionals’ blog, a public library workers’ blog, a "human search engine” or reference blog, etc. Table 12 shows the subject focus of the organisational blogs. 


\begin{tabular}{|l|r|r|}
\hline \multicolumn{1}{|c|}{ Subject focus/topic of the blog } & Number & Percentage \\
\hline News and current events & 14 & 26.92 \\
\hline Library-related & 26 & 50 \\
\hline $\begin{array}{l}\text { Computers and information } \\
\text { technology }\end{array}$ & 2 & 3.85 \\
\hline Advocacy group for the homeless & 1 & 1.92 \\
\hline Writers and literature lovers & 1 & 1.92 \\
\hline Gaming & 1 & 1.92 \\
\hline Parenting & 1 & 1.92 \\
\hline A "fact tank" & 1 & 1.92 \\
\hline Retail & 1 & 1.92 \\
\hline Religion & 1 & 1.92 \\
\hline Etiquette & 1 & 1.92 \\
\hline Feminist & 1 & 1.92 \\
\hline Advocacy group for homosexuals & 1 & 1.92 \\
\hline Total & $\mathbf{5 2}$ & $\mathbf{1 0 0}$ \\
\hline
\end{tabular}

Table 12: Subject focus of the organisational blog 


\section{Conclusion and Suggestions for Further Research}

The purpose of this study was to gain some insights into what is written about angry library patrons in the blogosphere. Three main themes which emerged in the qualitative content analysis of blog posts were: 1) causes of anger; 2) how anger was displayed; 3) and the sentiments of library staff members towards these angry patrons.

While the cause of anger in most angry library patron literature is often attributed to an unpopular library policy or procedure or a breakdown in communication between a library staff member and a patron, it turns out that a number of patrons become angry because of the actions and behaviours of other patrons in the library. Moreover, various technology/computer-related causes such as frustrations in using the online catalogue and ebooks and even the online porn-viewing habits of some patrons also now play a major part in angering library patrons.

The library patrons' anger is usually directed towards either library items or the staff members. The ways they express their anger can be relatively mild or severe which usually involves verbal abuse or violence. No library blogger mentioned being significantly affected by an angry patron though. Most of the blog posts originated from North America and only a small percentage of the posts were written by library patrons. It would have been interesting if more blog posts had been retrieved from other parts of the world and from the perspectives of more patrons.

Two main limitations exist in this study. The first one is that only seven keywords were used to search the blogosphere and the second one is that only Google Blogs was used to search for a sample of blogs. There might have been different results from a long list of keywords and various keyword combinations. Results may also be different if two or more blogosphere search engines had been used. Doing that could form the basis of a future research.

Further research could be done by retrieving blog posts strictly written by library patrons to get their point of view. Another option for research is to look further into anger/annoyance/irritation issues which are caused by other library patrons. A simple search on snoring, sleeping, and smelly library patrons yield a lot of interesting results. 


\section{References}

Aharony, N. (2009a). An exploratory analysis of librarians' blogs: their development, nature and changes. Aslib Proceedings, 61(6), 587-604.

doi:http://dx.doi.org/10.1108/00012530911005535

Aharony, N. (2009b). Librarians and information scientists in the blogosphere: an exploratory analysis. Library and Information Science Research, 31(3), 174-181. http://dx.doi.org/10.1016/j.lisr.2009.02.001

Aharony, N. (2010). LIS Blog Comments: An Exploratory Analysis. Libri: International Journal of Libraries \& Information Services, 60(1), 65-77. Retrieved from Library Literature \& Information Science Full Text database.

Beck, S.E. \& Manuel, K. (2008). Content analysis. In Practical research methods for librarians and information professionals (pp. 35-65). New York, NY: Neal Schuman.

Bee, V. (2001). Problem patrons and New Zealand university libraries. Unpublished MLIS research project, Victoria University of Wellington, Wellington, New Zealand.

Bar-Ilan, J. (2007). "The use of Weblogs (blogs) by librarians and libraries to disseminate information" Information Research, 12(4) paper 323. Retrieved from http://informationr.net/ir/12-4/paper323.html?pagewanted=all

Blessinger, K.D. (2002). Problem patrons: All shapes and sizes. In K. Sarkodie-Mensah (Ed.), Helping the difficult library patron: New approaches to examining and resolving a long-standing ongoing problem (pp. 3-10). New York, NY: Haworth Information Press, 2002.

Blood, R. (2004). How Blogging Software reshapes the online community. Communications of the ACM, 47(12), 53-55. Retrieved from Business Source Complete database.

Boyd, C. (2002). Customer violence and employee health and safety. Work, employment, and society, 16(1), 151-169. Retrieved from Sage Premier database.

Brookover, S. (2007). Why we blog. Library Journal, 132(19), 28. Retrieved from ProQuest Central database 
Bullard, S. W. (2002). Gypsies, Tramps and Rage: Coping with Difficult Patrons. Reference Librarian, 36(75/76), 245-252. Retrieved from LISA database.

Bunge, C. (1987). Stress in the library. Library journal, 112(15), 47-51. Retrieved from Business Source Complete database.

Crosby, C. (2010). Introduction: blogging basics. In Effective blogging for libraries (pp. 110). New York, NY: Neal Schuman.

Dvorak, J.C. (2002, February 5). The blog phenomenon. PC Magazine. Retrieved from http://www.pcmag.com/article2/0,2817,12899,00.asp

Farkas, M. (2007). The bloggers among us. Library Journal, 132(20), 40. Retrieved from ProQuest Central database.

Farrugia, S. (2002). A dangerous occupation? Violence in public libraries. New Library World, 103(9), 309-319. Retrieved from ProQuest Central database.

Gannon-Leary, P. \& McCarthy, M.D. (2010). Dealing with challenging situations. In Customer care: A training manual for library staff (pp. 125-147). Oxford, UK: Chandos.

Gelber, N. (2011). Blogging on the profession: a closer look into personal cataloging and metadata weblogs. Technical Services Quarterly, 28(4), 385-405. http://dx.doi.org/10.1080/07317131.2011.597688

Gorman, M. (1983, October). A borrower is a client is a patron is a user is a reader: or, Gertrude Stein, where are you now that we need you? American Libraries, 14, 597. Retrieved from Academic OneFile database.

Grandey, A.A., Dickter, D.N., \& Sin, H.P. (2004). The customer is not always right: Customer aggression and emotion regulation of service employees. Journal of Organizational Behavior, 25(3), 397-418. Retrieved from ProQuest Central database.

Grove, S. J., Fisk, R. P., \& John, J. (2004). Surviving in the age of rage. Marketing Management, 13(2), 41-46. Retrieved from Business Source Complete database. 
Harris, L.C. \& Reynolds, K.L. (2003). The consequences of dysfunctional customer behavior. Journal of Service Research : JSR, 6(2), 144-161. Retrieved from ProQuest Central database.

Hookway, N. (2008). Entering the blogosphere: some strategies for using blogs in social research. Qualitative Research, 8(1) (91-113). doi: 10.1177/1468794107085298

Hsieh, H. \& Shannon, S.E. (2005). Three approaches to qualitative content analysis. Qualitative Health Research, 15(9), 1277-1288. Retrieved from Sage Premier database.

Kean, C., \& McKoy-Johnson, F. (2009). Patron aggression in the academic library: A study of the main library at the University of the West Indies, Mona. New Library World, 110(7-8), 373-384. Retrieved from LISA database.

Lee, C.M. \& Bates, J. A. (2007). Mapping the Irish biblioblogosphere. The Electronic Library, 25(6), 648-663. doi:http://dx.doi.org/10.1108/02640470710837092

Mathews, B. (2010). Customer's always right. American Libraries, 41(9), 49. Retrieved from ProQuest Central database.

McGrath, H., \& Goulding, A. (1996). Part of the job: Violence in public libraries. New Library World, 97(1127), 4-13. Retrieved from ProQuest Central database.

McGuigan, G. S. (2002). The Common Sense of Customer Service: Employing Advice from the Trade and Popular Literature of Business to Interactions with Irate Patrons in Libraries. Reference Librarian, 36(75/76), 197-204. Retrieved from LISA database.

Nardi, B.A., Schiano, D.J., Gumbrecht, M. and Swartz, L. (2004). I'm blogging this: a closer look at why people blog. Retrieved July, 3, 2013, from http://www.dourish.com/classes/ics234cw04/nardi.pdf

Neuman, W. L. (2012). Nonreactive research and secondary analysis. In Basics of social research: qualitative and quantitative approaches (pp. 237-260). Boston, MA: Pearson Education.

Moorcroft, H. (2009). The Perfect Place to Work? Australian Academic Libraries and Unacceptable Behaviour. Australian Academic \& Research Libraries, 40(3), 206222. Retrieved from Library Literature \& Information Science Full Text database. 
Osa, J. O. (2002). The Difficult Patron Situation: Competency-Based Training to Empower Frontline Staff. Reference Librarian, 36(75/76), 263-276. Retrieved from LISA database.

Patterson, P. G., McColl-Kennedy, J. R., Smith, A. K., \& Lu, Z. (2009). Customer Rage: triggers, tipping points and take-outs. California Management Review, 52(1), 6-28. Retrieved from Business Source Complete database.

Pedersen, S. (2010). Why blog?: motivations for blogging. Oxford, England: Chandos.

Rach. (2011, January 3). Living in the library world. [Defusing the angry patron]. Retrieved from http://livinginthelibraryworld.blogspot.com/2011/01/defusing-angrypatron.html

Reed, V. (2008, March). Whom do we serve? a patron by any other name might get sweeter service. Reference Librarian. 183-185. Retrieved from Education Research Complete database

Rubin, R.J. (2000). Defusing the angry patron: A how-to-do-it manual for librarians and paraprofessionals. New York, NY: Neal-Schuman.

Sauers, M.P. (2006). An introduction to blogs. In Blogging and RSS: a librarian's guide (pp. 1-9). Medford, NJ: Information Today.

Shah, S. G. S., \& Robinson, I. (2011). Patients' perspectives on self-testing of oral anticoagulation therapy: Content analysis of patients' internet blogs. BMC Health Services Research, 11(1), 25. doi:http://dx.doi.org/10.1186/1472-6963-11-25

Sheih, C.S. (2010). An empirical study of public service librarians' perceptions and causes of negative emotions in Taiwan's public libraries. Journal of Library and Information Studies, 8(1), 59-96. Retrieved from http://jlis.lis.ntu.edu.tw/article/v8-1-4.pdf.

Spurgin, K. \& Wildemuth, B.M. (2009). Content analysis. In Wildemuth, B.M. Applications of social research methods to questions in information and library science (pp. 297319). Westport, CT: Libraries Unlimited.

Steffen, N. O. (2000). Rising to the occasion: working with angry people at the reference desk. Colorado Libraries, 26(2), 11-13. Retrieved from Library Literature \& Information Science Full Text database. 
Stephens, M. (2008). The pragmatic biblioblogger: examining the motivations and observations of early adopter librarian bloggers. Internet Reference Services Quarterly, 13(4) 311-345. http://dx.doi.org/10.1080/10875300802326475

Sudweeks, F. \& Rafaeli, S. (1995). How do you get a hundred strangers to agree?. In T.M. Harrison and T.D. Stephen (Eds.) Computer networking and scholarship in the $21^{\text {st }}$ century university. New York, N.Y.: Suny Press.

Turner, A.M. (2004). Dealing with angry people. In It comes with the territory: Handling problem situations in libraries (pp. 35-44). Jefferson, NC: McFarland \& Company.

Walther, J.B. (2002). Research ethics in internet-enabled research: human subjects issues and methodological myopia. Ethics and information technology 4, 205-216. Retrieved from ProQuest Central database.

White, M. D., \& Marsh, E. E. (2006). Content analysis: A flexible methodology. Library Trends, 55(1), 22-23,27-34,36-45. Retrieved from ProQuest Central. 


\section{Appendix: List of Blogs}

http://jleuzinger.blogspot.com/2006/07/book-review-defusing-angry-patron.html

http://librarysupporter.blogspot.com/2005/04/powerpoint-companion-to-defusing-angry.html http://lifeinoleg.com/librarianship/ref-desk-besties-2

http://awesomebrarian.com/2011/03/14/lessons-in-gilesdom-6-dealing-with-angry-birdspatrons/

http://livinginthelibraryworld.blogspot.com/2011/01/defusing-angry-patron.html http://libtechlitreviews.wordpress.com/2012/10/11/difficulties-with-patrons/ http://ciaofromdonna.wordpress.com/2007/08/31/angry-patron/ http://kristybowen.blogspot.com/2011/11/horror-lover-that-i-am-i-have-zombie.html http://joannareads.com/2011/02/02/irony-library-student-with-delinquent-patron-record/ http://www.librarian.net/stax/2191/technostress-and-jerks-in-the-library/ http://magpielibrarian.wordpress.com/2012/07/09/please-dont-say-this-to-a-librarian/ http://www.screwydecimal.com/2010/10/too-much-info-for-this-info.html http://www.lezbrarian.com/2012/04/30/tales-from-the-music-library/ http://mylibraryideas.wordpress.com/2008/07/24/the-patron-awards/ http://exploringfeminisms.com/2012/06/11/the-public-library-six-months-in-the-trenches/ http://yoru-yume.livejournal.com/87943.html http://www.libraryquirks.org/children/as-long-as-we-keep-silent-this-will-continue/ http://funktious.wordpress.com/2012/02/08/angry-person-is-angry/ http://www.l1brar1an.com/?p=831

http://library.sfsu.edu/blogs/lsp/2011/11/14/security-issues-in-annex-1/ http://cityroom.blogs.nytimes.com/2009/08/19/a-librarys-approach-to-books-thatoffend/? r $=0$

http://awfullibrarybooks.net/do-not-provoke-the-librarian/ http://voicesofyouthserviceslibrarians.blogspot.com/2012/12/kelly-keefer.html http://ndlaonline.org/ifblog/?p=170 http://blogs.windsorstar.com/2012/12/10/library-books-vandalized-with-urine/ http://blog.librarylaw.com/librarylaw/2005/09/query may a pub 1.html http://lisnpn.spruz.com/pt/Circulation-librarians-patron-saints-of-borrowers/blog.htm 
http://nicbits.blogspot.com/2012/03/pla12-help-i-am-librarian-not-social.html

http://researchquest.blogspot.com/2007/09/library-arcade-carnegie-mellon-librarys.html http://www.retailhellunderground.com/my_weblog/2010/07/rude-library-patron-custy.html http://www.geekculture.com/cgibin/ultimatebb/ultimatebb.cgi?ubb=get topic; $f=9 ; t=003208 ; p=$

http://www.librarianshit.com/safeplace/

http://arsl.info/2012/02/you-know-you-are-a-rural-librarian-if/

http://tplfans.wordpress.com/2013/05/

http://www.bohyunkim.net/blog/archives/2287

http://librarianinblack.net/librarianinblack/2011/04/just-say-no-to-freegal.html

http://laureltarulli.wordpress.com/2009/12/30/social-tagging-in-the-catalogue-you-allow-that/ http://www.swissarmylibrarian.net/2009/10/27/serve-the-community-or-serve-the-individual/ http://mjwarnock.blogspot.com/2009/02/library-patrons-are-wierd-bunch.html http://www.washingtoncitypaper.com/blogs/housingcomplex/2013/02/27/off-the-books/ http://lisnews.org/a library patron observes his surroundings and finds many reasons to _complain

http://www.womenofgrace.com/blog/?p=11501

http://parklabreanewsbeverlypress.com/news/2013/03/book-closed-on-wesson\%E2\%80\%99sall-digital-library-proposal/

http://www.wrightcountylibrary.org/2011/11/21/collection-policy/

http://newstimes.augusta.com/latest-news/2011-11-22/controversial-book-added-back-tolibrary-shelves

http://jezebel.com/5533592/mom-refuses-to-return-racy-gossip-girl-books-to-library http://cityroom.blogs.nytimes.com/2010/04/09/complaint-box-the-lost-library-voice/? $\mathrm{r}=0$ http://middletown-ct.patch.com/groups/politics-and-elections/p/russell-library-closed-afterbed-bugs-found

http://thestir.cafemom.com/baby/142211/momfriendly_library_kindly_banishes_breastfeedin g

http://occupiedtucsoncitizen.org/?p=1875

http://lj.libraryjournal.com/blogs/annoyedlibrarian/2011/09/28/what-librarians-censor/

http://www.etiquettehell.com/?p=3763 
http://www.sott.net/article/241346-US-Washington-Seattle-Library-Lets-Man-Watch-Pornin-View-of-Children

http://bestofpublib.wordpress.com/2011/06/23/libraries-and-flatulence/

http://snovalleystar.com/2013/04/03/residents-complain-about-behavior-at-north-bend-library

http://safelibraries.blogspot.com/2009/12/porn-in-brooklyn-public-library.html

http://livinginthelibraryworld.blogspot.com/2011/01/defusing-angry-patron.html

http://anglo-celtic-connections.blogspot.com/2013/04/more-ebooks-coming-to-canadianpublic.html

http://librarianbyday.net/2012/02/09/how-to-talk-to-your-patrons-about-penguin-otherpublishers-not-loaning-ebooks-to-libraries/

http://kraftylibrarian.com/?p=747

http://www.web2learning.net/2007/10/31/patrons-frustrations/

http://goodereader.com/blog/electronic-readers/public-libraries-work-to-meet-patron-demandfor-ebooks/

http://www.publiclibraries.com/blog/publishers-could-use-movie-release-windows-forebooks-at-libraries/

http://annarborchronicle.com/2011/04/28/ann-arbor-library-signs-digital-music-deal/

http://www.utk.edu/tntoday/2012/10/04/hodges-library-online-maps/

http://solisusf.wordpress.com/2013/02/13/how-libraries-meet-the-needs-of-their-patrons-howthe-pinellas-public-library-cooperative-is-meeting-the-needs-of-the-deaf-community/

http://www.textalibrarian.com/mobileref/4-ways-an-ask-a-librarian-presence-on-your-onlinedatabases-empowers-your-library/

http://info.askalibrarian.org/2013/04/01/october-2012-exemplary-reference-awards/

http://libraries.pewinternet.org/2013/05/01/part-7-librarians-thoughts/

http://thehyperlinkedlibrary.org/hyperlib/amysblog/2013/02/10/kindness/

http://courtneyschoenfeld.wordpress.com/2011/10/13/dear-library-patrons/

http://livinginthelibraryworld.blogspot.com/2011/01/handling-problem-situations.html

http://www.lauraek.net/2010/09/10/the-endless-complications-of-smut-in-the-library/

http://fremontlibraries.wordpress.com/2011/08/27/love-your-library-then-treat-it-kindly/

http://maricopacountysuperiorcourtlibrary.wordpress.com/2012/01/11/libraries-are-

proposing-rules-to-battle-offensive-behavior/

http://notabibliothecae.blogspot.com/2008/07/i-recently.html

http://www.housethehomeless.org/homelessness-and-public-libraries/ 
http://www.stateuniversity.com/blog/permalink/Studying-at-the-Library-Bad-PatronBehaviors.html

http://slog.thestranger.com/slog/archives/2012/01/31/a-mothers-crusade-to-remove-hardcorepornography-from-the-middle-of-seattle-libraries

http://pluggedinlibrarian.blogspot.com/2011/11/penguin-kindle-format-disappears-from.html http://safelibraries.blogspot.com/2013/04/ChicagoPublicLibrary.html

http://mycropht.blogspot.com/2006/03/hermitage-branch-library-violates.html

http://erikagebhardt.com/2011/02/15/postpartum-hormone-update/

http://www.swissarmylibrarian.net/2010/04/28/mla2010-black-belt-librarians-dealing-withdifficult-patrons/

http://www.publiclibraries.com/blog/public-libraries-could-be-the-ultimate-way-to-promoteebooks/

http://litreactor.com/news/san-francisco-public-library-installs-porn-shields

http://readallaboutus.net/2013/03/15/continued-patron-support-evident-at-mini-rally/

http://inalj.com/?p=19704

http://ex-gaytruth.com/ex-gay-news/pfox-report-and-advice-on-an-ex-gay-library-exhibit/

http://b-townblog.com/2012/10/13/resident-upset-with-king-county-library-after-niecechecks-out-explicit-anime-book/

http://olcsmalllibraries.wordpress.com/2011/05/10/the-first-30-seconds-helping-front-linestaff-respond-to-challenges/

http://lisnews.org/man_upset_about_losing_library 